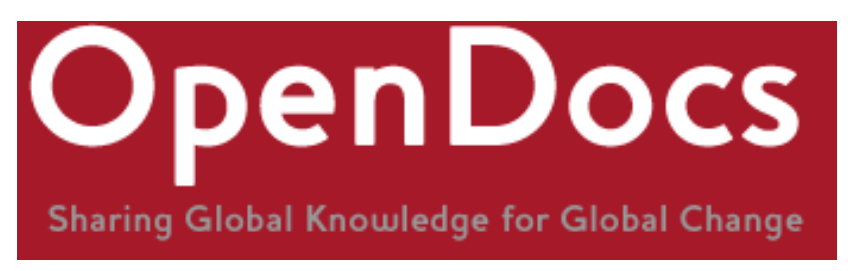

Title: Linking agricultural development to school feeding in sub-Saharan Africa: theoretical perspectives

Citation: Sumberg, J., R. Sabates-Wheeler. (2011). Linking agricultural development to school feeding in sub-Saharan Africa: theoretical perspectives. Food Policy 36(3): 341-349

Official URL: http://www.sciencedirect.com/science/article/pii/S0306919211000406

More details/abstract: This paper takes as a starting point the proposition that social protection interventions involving food can be used to promote transformational change in family farming systems in sub-Saharan Africa. The purpose is to highlight the complexity of pathways to agricultural transformation associated with the seemingly simple idea of homegrown school feeding (HGSF), an idea that is increasingly held up as "win-win". By reviewing the HGSF literature and the main theories underpinning it - structured demand, localism, family farmer development - we expose areas of inconsistency across the literature and programmes as well as possible tensions that may arise in attempting to pursue both market and social objectives in the same initiative. The arguments presented herein aim to provide a basis for moving towards clarity on (1) a theory of change for HGSF programmes; (2) the conditions under which HGSF programmes are more able to yield positive agricultural development outcomes and; (3) an agenda for moving forward on research and impact evaluation. This research agenda also speaks more broadly to important under-researched areas within the general social protection and agricultural development discourse.

Version: Submitted version

Terms of use: This work has been licensed by the copyright holder for distribution in electronic format via any medium for the lifetime of the OpenDocs repository for the purpose of free access without charge. The final published version is available at http://www.sciencedirect.com/science/article/pii/S0306919211000406

This is a download from OpenDocs at the Institute of Development Studies

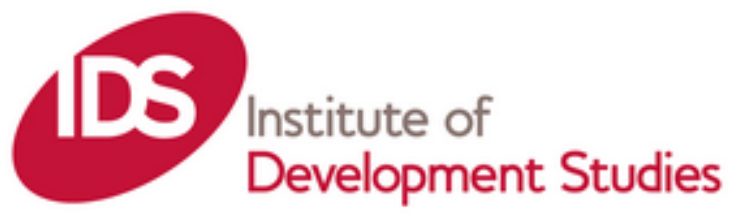




\title{
Linking agricultural development to school feeding in sub- Saharan Africa: theoretical perspectives
}

\author{
James Sumberg*, Rachel Sabates-Wheeler \\ Institute of Development Studies (IDS), University of Sussex, Brighton BN1 9RE, UK \\ *Corresponding author. Tel +44 (0)1273 915833; fax: +44 (0)1273 621202 \\ E-mail addresses: j.sumberg@ids.ac.uk; r.sabates-wheeler@ids.ac.uk
}

\begin{abstract}
This paper takes as a starting point the proposition that social protection interventions involving food can be used to promote transformational change in family farming systems in sub-Saharan Africa. The purpose is to highlight the complexity of pathways to agricultural transformation associated with the seemingly simple idea of home-grown school feeding (HGSF), an idea that is increasingly held up as "win-win". By reviewing the HGSF literature and the main theories underpinning it - structured demand, localism, family farmer development - we expose areas of inconsistency across the literature and programmes as well as possible tensions that may arise in attempting to pursue both market and social objectives in the same initiative. The arguments presented herein aim to provide a basis for moving towards clarity on (1) a theory of change for HGSF programmes; (2) the conditions under which HGSF programmes are more able to yield positive agricultural development outcomes and; (3) an agenda for moving forward on research and impact evaluation. This research agenda also speaks more broadly to important under-researched areas within the general social protection and agricultural development discourse.
\end{abstract}

Key Words: social protection, home-grown school feeding, agriculture, structured demand, procurement

Pre-print version. Eventually published as: Sumberg, J., R. Sabates-Wheeler. (2011). Linking agricultural development to school feeding in sub-Saharan Africa: theoretical perspectives. Food Policy 36(3): 341-349 


\section{Introduction}

Interest in "win-win" solutions and the recent convergence of policy debates relating to agriculture and social protection draw attention to the relationship between agricultural development and social protection interventions in sub-Saharan Africa (SSA). The conventional view is that agricultural policies promote productivity enhancement and income growth, while social protection seeks to stabilise yields and consumption (especially when production fails). However this view is being challenged by emerging evidence which suggests that in some contexts both objectives can be achieved with a single instrument (Dorward et al. 2006; Sabates-Wheeler et al. 2009). Interlinking of "social" and "economic" policies for poor farmers was anticipated by debates in the 1990s around "linking relief and development" and "productivity-enhancing safety nets". However this link has been brought into sharper focus by the "colonisation" of many traditional agricultural policy instruments by social protection, including crop insurance, agricultural input subsidies and even grain futures markets (Dorward et al. 2006).

School feeding is a classic and well established "provisioning" type of social protection programme. By providing children with meals, snacks or take-home rations, school feeding programmes seek first and foremost to overcome food and nutritional deficiencies. However, the fact that school feeding can also improve enrolment (particularly for girls) and learning outcomes (Bundy et al. 2009, Kristjansson et al. 2007) suggests that over the medium to long term it could have important promotional as well as transformational effects (i.e. by building human capital and/or empowering girls relative to boys by overcoming educational access bias). ${ }^{1}$

In recent years there have been signs of a significant shift in thinking about school feeding (Morgan and Sonnino 2008; Bundy et al. 2009), and many elements of this new thinking are being actively promoted under the rubric of "home grown school feeding" (HGSF) (Espejo et al. 2009). HGSF is of particular interest as it provides an example of an intervention that claims to have the potential to deliver the positive linkages or synergies between social protection and agricultural development referred to above.

HGSF has been defined in a variety of ways (e.g. Espejo et al. 2009; Morgan et al. 2007; and the Comprehensive African Agricultural Development Programme (CAADP)) $)^{2}$, but the common element that links these various definitions is the notion that HGSF attempts to actively and explicitly link agricultural development with school feeding. ${ }^{3}$ There is less agreement in relation to the scale at which this linkage might take place (the terms "local", "within a country" and "domestically produced" are all used, sometimes interchangeably) and the linkage mechanisms themselves are seldom specified (Sumberg and SabatesWheeler 2010).

Over the last five years HGSF has received increasing attention from international agencies (Sanchez et al. 2005), funders, national policy makers and governments, academics (Morgan

\footnotetext{
${ }^{1}$ See Sabates-Wheeler and Devereux (2009) for a discussion of the different functions of social protection.

${ }^{2}$ CAADP is NEPAD's Comprehensive African Agriculture Development Programme (www.nepadcaadp.net/). The programme's Pillar 3 (Food supply and hunger) specifically highlights home-grown school feeding (http://www.nepad-caadp.net/pillar-3.php).

${ }^{3}$ Some proponents suggest that school gardens can or should be a considered a component of HGSF, despite the fact that time spent gardening may not be consistent with the objectives of schooling. Here we do not consider school gardens as part of HGSF.
} 
et al. 2007) and practitioners (Espejo et al. 2009). The Bill and Melinda Gates Foundation (BMGF) has funded or co-funded some of these activities as well as other closely related initiatives such as the World Food Programme's (WFP) Purchase-for-Progress (P4P) programme. ${ }^{4}$ Outline information on three on-going HGSF programmes is given in Table 1. It is clear that these programmes are quite different in important ways: there is unified model of HGSF.

Those who argue that HGSF can successfully deliver both social protection and agricultural development draws heavily from experiences in Chile and Brazil (Morgan et al. 2007; Espejo et al. 2009). In relation to SSA the narrative that is commonly used to justify the promotion of the HGSF approach has three parts as follows:

1. The agricultural sector and the livelihoods of family farmers in SSA can be transformed for the better through greater engagement with markets.

2. This transformational potential is presently constrained by the failure of input and output markets, poor infrastructure and sub-optimal use of productivity enhancing technology.

3. However, by "structuring" demand in ways that make it easier, less risky and more profitable for family farmers to engage with markets, and by providing an array of complimentary services (training, credit, access to technology), food procurement for social protection programmes (such as school feeding) can be used to kick start this market-based transformational process.

This paper uses the case of HGSF to explore the proposition that social protection and agricultural growth can be achieved through a single intervention. Given the increasing interest in (and significant resources devoted to) HGSF as a tool for positive agricultural change, as well as the dearth of empirical evidence on the validity of the HGSF proposition, our paper intends to make a critical, timely and constructive contribution. Specifically, we aim to unpack the theory and assumptions underlying the HGSF agenda and situate notions of "structured demand" and "localisation" within the appropriate literatures in order to draw lessons that bear on HGSF. The paper proceeds as follows. In the next section we elaborate and explore the theory of change underlying HGSF. We then use this theory to identify the potential benefits that could be associated with HGSF and ask if, how, when, where and for whom these benefits are likely to be "transformative". The paper concludes with some suggestions for further research. The focus throughout is on sub-Saharan Africa. 
Table 1. Three on-going HGSF programmes

\begin{tabular}{|c|c|c|c|}
\hline & \multicolumn{3}{|c|}{ Location } \\
\hline Stated objective (s) & $\begin{array}{l}\text { Development objective: contribute } \\
\text { to poverty reduction \& food } \\
\text { security. } \\
\text { - Immediate objective: boost } \\
\text { domestic food production. } \\
\text { (GSFP AOP, 2009) }\end{array}$ & 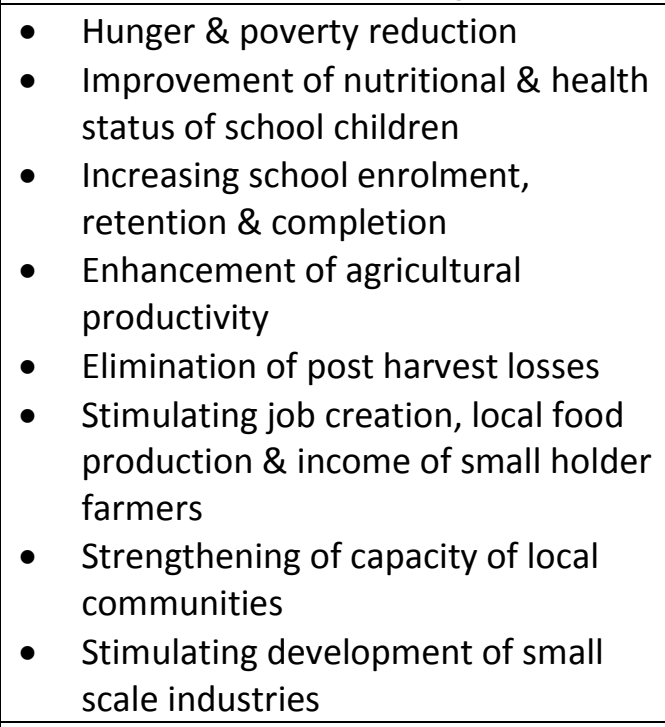 & $\begin{array}{l}\text { - To strengthen the capacity of } \\
\text { stakeholders at all levels to } \\
\text { implement school health, nutrition } \\
\text { \& meals programmes. } \\
\text { - To have a framework to regulate, } \\
\text { coordinate \& ensure standards in } \\
\text { implementation of school health, } \\
\text { nutrition \& meals programmes. } \\
\text { - To enhance a comprehensive, } \\
\text { effective, efficient \& sustainable } \\
\text { monitoring \& evaluation system. } \\
\text { (Kenya HGSF ITGM, 2009) }\end{array}$ \\
\hline $\begin{array}{l}\text { Implementation } \\
\text { strategy }\end{array}$ & $\begin{array}{l}\text { - Through District Assemblies } \\
\text { - Caterer at school-level responsible } \\
\text { for procurement \& preparation of } \\
\text { food }\end{array}$ & $\begin{array}{l}\text { - One cook per } 50 \text { students } \\
\text { - Food purchased by cooks at local } \\
\text { markets } \\
\text { - Cash transfer to cooks' bank } \\
\text { accounts every two weeks }\end{array}$ & $\begin{array}{l}\text { - Competitive tendering for food \& } \\
\text { transport with registered farmers \& } \\
\text { suppliers } \\
\text { - Coordinated by local school meals } \\
\text { committees }\end{array}$ \\
\hline Funding & $\begin{array}{l}\text { - Government of Ghana } \\
\text { - Bi-lateral funding from Netherlands }\end{array}$ & - State \& local government & $\begin{array}{l}\text { - Government of Kenya } \\
\text { - } \quad \text { Bi-lateral funding from Japan }\end{array}$ \\
\hline
\end{tabular}




\section{Theory of change}

As highlighted above and depicted schematically in Figure 1, the theory underpinning HGSF is that the social protection benefits and the agricultural development benefits associated with HGSF - working in parallel and interacting - will be powerful enough to kick start the transformation of agriculture and subsequently of rural livelihoods in SSA. In this section we explore the agricultural development aspects of this theory in more detail.

Figure 1. Linking social protection to agricultural benefits: a win-win scenario?

Figure 1 here

The HGSF theory of change combines ideas from two sources. The first is essentially the current orthodoxy about agricultural development in $\mathrm{SSA}^{5}$, while the second is a set of ideas around the strategic use of public procurement, "demand-assisted growth" and economic localisation. The theory of change brings together elements from these two sources in eight logical steps as follows:

1. Agricultural growth is essential for broad-based poverty reduction in SSA.

2. Agricultural growth will come about through increased engagement with input and output markets, which will stimulate technical change and result in productivity enhancement.

3. The greatest poverty reduction impact of this "market engagement - agricultural growth - poverty reduction" linkage will come via a focus on small or family farms.

4. A major block to greater market engagement by family farmers is the fact that in much of rural SSA input and output markets are thin, seasonal and poorly governed; infrastructure is poor etc.

5. These market constraints can be addressed by using the public sector demand for food associated with social protection programmes (like school feeding) to drive a demand-assisted agricultural growth strategy. The demand for this food can be "structured" so that it is easier, less costly and less risky for specific target groups within the population of family farmers to engage with input and output markets.

6. Social protection programmes involving food are prime candidates for a structured demand approach for two reasons: there is growing recognition among both funders and recipient countries of the benefits of substituting domestically produced commodities for food aid and imported commodities; demand is highly predictable and thus amenable to a structuring process that will reduce the uncertainty and risk associated with family farmers' engagement with food markets.

7. The provision of complimentary services (training, credit, access to inputs and technology) can be linked to the process of structuring demand.

\footnotetext{
${ }^{5}$ An alternative to this orthodoxy is put forward by the "food sovereignty" movement (MartinezTorres and Rosset 2010).
} 
8. Thus, the use of structured demand to supply school feeding programmes is an attractive avenue through which to kick start a process of agricultural and livelihood transformation.

The notion that public sector procurement can serve as a powerful tool to advance economic development (e.g. through small enterprise development) is well established. However, to date this notion has not been given a prominent place in agricultural development policy in SSA. Similarly, with the exception of some smaller-scale NGO programmes and WFP's relatively recent Purchase-for-Progress initiative, localisation strategies and structured demand have not figured prominently within agricultural development programmes in SSA.

There is some obvious resonance between the HGSF theory of change and the literature on balanced and unbalanced growth (see Lipton 1962; Kremer 1963) especially in relation to structured demand; the centrality of the state's involvement in this structuring; the multiplier effects, and; the presumed supply response. In effect, the dominant assumption underpinning the success of HGSF is that output incentives will induce an investment response and that this will lead to growth in and outside the agricultural sector. Tendler and Amorim (1996) described this approach in terms of "demand-assisted growth". More recently, the role of public procurement in promoting sustainability, environmental and social agendas has been highlighted in both the North (e.g. Eckersley 2004; McCrudden 2004) and the South (Bolton 2008; Geng and Doberstein 2008). The basic proposition is that the immense purchasing power of the state can be used in a strategic, pro-active and innovative manner to favour different suppliers, regions and products - and ultimately transformative outcomes - compared to more standard "least cost" or "value for money" procurement approaches. The particular example of procurement of food for schools has been explored in some detail (Morgan 2008; Morgan and Sonnino 2008; Sonnino 2009).

The second novel element of the HGSF theory of change relates to the rise of interest in the processes of economic localisation, which has been portrayed by some observers as a reaction to the era of globalisation. While the notions local and localisation are problematic from both conceptual and operational perspectives, it has nevertheless been suggested that efforts to localise (or re-localise) economic activity could or should be the centre-piece of development programmes addressing issues such as unemployment, inequality and vulnerability to climate change. Thinking along these lines is also central to the "food sovereignty" agenda and its alternative vision for agriculture and rural development worldwide (Martinez-Torres and Rosset 2010). The social, economic and environmental implications of re-localisating food and food systems have received particular attention over the last decade (Winter 2003; Hinrichs 2003; DuPuis and Goodman 2005; Born and Purcell 2006). ${ }^{6}$ The movement toward domestic (and regional) procurement of food aid can also be seen in the light of new understandings of the range of benefits (i.e. to farmers, traders, transporters and food aid beneficiaries) that can be derived from more localised public food procurement strategies (Maxwell 2007; del Ninno et al. 2007; Lentz and Barrett 2008; Tadesse and Shively 2009).

The third novel element addresses the conventional wisdom that in much of rural SSA the positive link between market engagement and investment in technology fails to materialise because agricultural input and output markets are thin and poorly governed, supporting institutions (e.g. providing research, extension and credit) are "weak" and many rural areas

\footnotetext{
${ }^{6}$ There are many claims and counter-claims associated with local food e.g. in relation to freshness, flavour, health benefits, relative environmental impacts etc. - see Edwards-Jones et al. (2008) for a recent review.
} 
are poorly served by transportation and communications infrastructure (Poulton et al. 2006). This analysis can be seen in terms of coordination risk, which Dorward and Kydd (2004) define as "the risk of failure of one player's investment due to the possible absence of complementary investments by other players in different stages in the supply chain." Coordination risk is particularly prevalent where there are thin markets and weak institutions. From the perspective of those interested in pro-poor agricultural development in SSA, "the central coordination challenge... is... how to develop supply chain systems that provide smallholders with access to the range of pre-harvest services that they require at the same time as enhancing their access to remunerative output market opportunities" (Dorward et al. 2005). For Barrett (2008, p.300), "One thus has to get institutions and endowments, as well as prices, 'right' in order to induce market-based development".

In the context of HGSF, coordination risk is addressed via structured demand. While this term is relatively new we argue that it has a long intellectual and policy pedigree, and probably links most directly to ideas and experience around "small-enterprise favouring procurement", "demand-driven models" and "demand-assisted [small enterprise] growth" (Tendler and Amorim 1996). These are in contrast to "supply-driven approaches" which "specialize in providing one or more ongoing services - credit, courses in business management, or technical assistance. They try to serve as many firms and as many sectors as possible" (Tendler and Amorim 1996). While these two approaches are not unrelated clearly the ambition of a demand-assisted approach is to stimulate a supply-side response but the critical question is which side (demand or supply) drives the intervention. To the extent that the supply side response is constrained through the coordination failures there may be a need to provide complementary services (e.g. training, credit and technical assistance) as part of a demand-driven model.

Drawing on these earlier experiences and linking them to the current interest in the use of structured markets or structured demand to drive HGSF (Bill \& Melinda Gates Foundation 2008,2009 ) we suggest that structured demand can be conceived of as demand-side market interventions that have the explicit objective of reducing coordination risk and specifically the barriers to entry and/or transactions costs faced by specific groups of potential suppliers. These demand-side interventions seek to create significant additional demand that is predictable over time. ${ }^{7}$ Depending on the circumstances they may be accompanied by supply-side measures (e.g. giving access to information, new technology, credit, training etc) and other longer-term, less-direct interventions (e.g. in relation to policy processes). While there are examples of private sector and NGO initiatives that could be described as using a structured demand approach, as a strategic development intervention the greatest potential would seem to sit with public sector procurement.

Operationally, demand is structured through procurement systems and procedures. The aspects that can be used to structure demand so as to encourage or facilitate engagement by family farmers include the specification of:

- The type, intrinsic qualities (e.g. quality standards etc) and extrinsic qualities (e.g. type of producer or geographical area of production) of the commodities to be purchased

- The quantity to be purchased (including number and size of lots )

- Delivery requirements (e.g. place, quantity, frequency, packaging)

\footnotetext{
${ }^{7}$ By "additional demand" we mean an increase in demand that is potentially satisfied by local family farmers. Thus, in the case of an existing school feeding programme where all food is presently imported, a shift to domestic procurement would be considered "additional demand" even though the total food consumed would not change.
} 
- The mechanism for price determination

- Any minimum requirements to become a "registered" or "licensed" supplier; any other restrictions on who can tender

- Contract details (e.g. mode and frequency of payment, upfront payments, default penalties, insurance requirements and so on)

In Figure 2 we bring the various elements of the HGSF theory of change into a single model. This model posits that by using a structured demand approach to make strategic use of public procurement, the local economy will be stimulated by the flow of direct benefits primarily to targeted groups, and indirect benefits, via multiplier and spill-over effects, to the local population mere widely. ${ }^{8}$ Fundamental to any view of HGSF as potentially transformative is the idea that it can act to kick start the cycle of economic activity depicted at the bottom of the figure. If HGSF is to live up to its billing, over the medium to long term, and eventually without the direct stimulus provided by HGSF programmes, this cycle must generate levels of opportunity and incentive sufficient to transform the agricultural sector and the rural livelihoods that are dependent upon it.

Figure 2. The HGSF model: theory of change

$<\quad$ Figure 2 here $>$

\section{Benefits \& beneficiaries}

In the light of the theory of change outlined above, in this section we look at agricultural and economic development benefits potentially associated with HGSF. These benefits can be divided between those that are direct (arising from expenditure for the purchase of food and additional marketing and income opportunities for food producers and suppliers) and those that are indirect (arising through spill-over and multiplier effects) (Table 2). They can also be divided between those that relate to income and those that relate to capital formation (i.e. human and social capital).

The procurement model used and the scale of HGSF purchases will determine the magnitude of direct benefits (increased income, income smoothing, human capital formation) and how these benefits are distributed between producers and other supply chain actors. In addition, the distribution of benefits within these groups of actors, as well as their spatial distribution will depend on how effectively any targeting strategy is operationalised through the procurement system.

\footnotetext{
${ }^{8}$ A number of commentators have already noted that if not handled carefully, attempts to establish this virtuous cycle through HGSF could potentially result in negative impacts. For example, if a programme's demand for food is large relative to the size of the "local" market, and there is no immediate supply response, prices could be driven up with negative consequences for poor people who rely on the same market for food provisioning (Stoppa (2007) modelled several scenarios along these lines). One obvious conclusion is that context and scale considerations must figure prominently in programme design. Similarly, if HGSF programmes offer a "limited" demand with a premium over local market prices, then it is highly likely that those producers or traders who 1) have 'know-how' about procurement systems and the associated paper work; 2) have political connections; and 3) can more readily assure quality, will be more likely to gain the market, and that this favourable position may become exacerbated overtime. Thus, the very process of setting up a system that is supposed to benefit poor family farmers, may in fact lead to exclusion of exactly those farmers from the process.
} 
Table 2. Direct and indirect agricultural and economic development benefits potentially associated with HGSF

\begin{tabular}{|c|c|c|c|c|}
\hline Type & Benefit & Beneficiaries & Mechanism & Benefit dependent on \\
\hline Direct & Increased income & $\begin{array}{l}\text { Producers } \\
\text { \&/or } \\
\text { other supply chain } \\
\text { actors }\end{array}$ & $\begin{array}{l}\text { Increased amount sold } \\
\text { Increase productivity }\end{array}$ & $\begin{array}{l}\text { The net additional demand represented by HGSF purchases; } \\
\text { proportion of marketed produce represented by HGSF } \\
\text { purchases } \\
\text { Supply response } \\
\text { Effectiveness of market mechanism(s) } \\
\text { Access to appropriate training, credit \& technology }\end{array}$ \\
\hline Direct & $\begin{array}{l}\text { Reduction in risk; more stable } \\
\text { income }\end{array}$ & $\begin{array}{l}\text { Producers } \\
\text { \&/or } \\
\text { other supply chain } \\
\text { actors }\end{array}$ & Predictability of demand & $\begin{array}{l}\text { Proportion of marketed produce represented by HGSF } \\
\text { purchases } \\
\text { Effectiveness of market mechanism(s) }\end{array}$ \\
\hline Direct & Human capital formation & $\begin{array}{l}\text { Producers } \\
\text { \&/or } \\
\text { other food chain } \\
\text { actors }\end{array}$ & $\begin{array}{l}\text { Experience, training \& capacity } \\
\text { building activities }\end{array}$ & Availability of appropriate \& effective technical training \\
\hline Indirect & Increased income & $\begin{array}{l}\text { People seeking jobs / } \\
\text { wages } \\
\text { Providers of non- } \\
\text { food goods \& } \\
\text { services } \\
\text { Producers \& other } \\
\text { food chain actors } \\
\text { Consumers }\end{array}$ & $\begin{array}{l}\text { Additional jobs / wages (via } \\
\text { multiplier effects) } \\
\text { Increased demand (via multiplier } \\
\text { effects) } \\
\text { Increased demand for food (via } \\
\text { multiplier effects) } \\
\text { Lower food prices (via spill-over } \\
\text { effects) }\end{array}$ & $\begin{array}{l}\text { Supply response to HGSF } \\
\text { Marginal labour requirements (e.g. by commodity \& } \\
\text { production system); quantities of commodities purchased by } \\
\text { HGSF; wage levels } \\
\text { Consumption preferences }\end{array}$ \\
\hline
\end{tabular}




\begin{tabular}{|l|l|c|c|l|}
\hline Indirect & Social capital formation & $\begin{array}{c}\text { Producers } \\
\text { \&/or } \\
\text { other food chain } \\
\text { actors }\end{array}$ & $\begin{array}{c}\text { Experience of working together } \\
\text { to fulfil contract (via spill-over } \\
\text { effects) }\end{array}$ & $\begin{array}{l}\text { Procurement strategy } \\
\text { Correct incentives being in place }\end{array}$ \\
\hline
\end{tabular}


The indirect benefits associated with an intervention such as HGSF could be many, widely distributed, and might be expected to develop over a long time frame. Some will certainly be unintended and unforeseen. The literature on local economy effects (Cooper and John 1988 ) is critical to understanding these indirect benefits and the pathways (and constraints) by which structured demand and thereby HGSF, is able to effect broader agricultural change and transformation.

\subsection{Factors moderating potential benefits}

The level and distribution of the potential direct and indirect benefits identified in Table 1 are mediated by a number of factors. We consider four of these below.

\subsubsection{Procurement strategies and spatial distribution of actors and benefits}

As structured demand is operationalised through procurement strategies, policies and procedures, it follows that the objectives and design characteristics of the procurement system will to a considerable degree determine the potential of HGSF programmes to deliver agricultural development benefits to family farmers. The degree to which this potential is realised will ultimately depend on how effectively the particular procurement system is implemented. Ultimately every procurement system entails multiple trade-offs, and it should be expected that the direct and indirect agricultural development benefits identified previously will be part of the trade-off calculus. It is not realistic or appropriate to assume that stimulating agricultural development can or should be the primary objective of a HGSF procurement system: rather, the primary objectives must be the provision a reliable supply of safe, appropriate food at a reasonable cost. Lipton (1962) makes a similar point in relation to balanced and unbalanced growth. These theories assume once-for-all State intervention; but they ignore the possibility of sustained reforms, initiated by the State, during the proposed development process. He argues that these 'demand-focussed' theories neglect the really 'radical' needs of development. For instance, do producers have access to the physical supplies they need to expand output in the face of higher demand? The central focus on demand assumes that resources are available and 'latent' producers simply need incentives to produce and become entrepreneurial. However, oftentimes resources are scarce. Low labour productivity, lack of knowledge, training, irrigation, fertiliser, etc, means that the supply of productive factors cannot rise in response to demand.

To illustrate the variety of procurement approaches that are being used in newly initiated HGSF programmes in SSA we sketch out three examples below. Each of these systems would have some claim to delivering HGSF, although presumably with different costs and resulting in different levels and distributions of agricultural development benefits:

- A cook, employed by a single school, goes to the nearby market on a weekly basis to purchase maize, cowpeas, oil and condiments. She negotiates with different traders in the market to get the best quality-price combination and pays them in cash.

- After a public tendering process a school district signs a contract with a nearby farmers association to supply a specified quantity of "locally produced" maize and cowpeas per month throughout the school year. A minimum price is set, but the contract specifies that if at the time of delivery the "market price" is higher the minimum price, the producers association will be paid the market price $+10 \%$. There is no provision for advance payment. The goods are collected by the school district every month and delivered to individual schools. Oil, condiments, vegetables and other perishables are purchased by the school cook from the local market as outlined above. 
- A national education ministry mandates its procurement office to publish a call for tenders in the national newspaper to supply, distribute and prepare food for a national school feeding programme. The call specifies that a minimum of $50 \%$ of all food must be produced domestically (within national borders) and that a suitable system must be put in place to monitor the proportion of domestic produce. The successful bidders must provide indemnity against default, and payments are made to the supplier one month in arrears.

Ultimately the interest is in understanding the effects of structuring demand through different procurement models, which, as seen in the three examples above, immediately highlights the spatial relations around HGSF. We can identify two potential spatial variables that might be important in relation to the level, type and/or distribution of benefits arising from HGSF. These are the degree to which producers are clustered and the proximity of producers to point of consumption. Combining these gives three spatial configurations:

1. Producers clustered; consumers nearby: e.g. a very decentralised model of school-level procurement primarily from nearby producers;

2. Producers clustered; consumers distant: e.g. a more centralised model where food is procured from clustered farmers in food surplus areas and shipped to distant schools;

3. Producers not clustered: e.g. a centralised model where food is procured with no specification of origin and shipped to distant schools.

Configuration 1 implies a very close link between the sites of production and consumption, which might be important in meeting local taste or quality preferences, in supplying very isolated schools or in supplying fresh or perishable produce. Configurations 1 and 2 allow for the clustering of producers and thus open the way for "peer monitoring, shared information and learning, quality control, group purchase, skills upgrading and backward and forward linkages", which Tendler and Amorim (1996) suggested were particularly important for demand-assisted small growth strategies. Configuration 2 and 3 imply more centralised procurement systems operating at larger scales and handling greater quantities, and are likely to require a more prominent role for intermediaries in the supply chain. Configuration 3 gives the greatest room to manoeuvre in terms of choice, quality, price etc. but is not very amenable to e.g. group learning and social capital formation amongst producers, and would likely make the provision of any accompanying supply-side measures both difficult and expensive.

A further implication of spatial configurations of HGSF relates to price effects. Local prices will depend both on market integration and on the size of the band between regions producing and consuming. For instance, local prices, both for the producer and the school, will depend on 1) whether the gain is being produced in a surplus or deficit region; 2) the transaction cost of exporting the food; 3 ) the price differential between where the food is produced and where it is consumed; and 4) the scale of food being introduced into local markets.

\subsubsection{Thresholds and scale effects}

HGSF seeks to achieve agricultural development and social protection objectives through one instrument, and because of this in many situations it will be necessary to undertake 
complimentary activities to enable poorer farmers to increase their engagement with markets. This is likely to require the programme (or an associated agency) subsidising training, providing technology "starter packs" or other complementary inputs and credit. In many ways this can be viewed as "protectionism" - i.e. shielding family farmers from full force of the market while they obtain some market advantage. This protectionism implicitly recognises that many poorer family farmers face initial thresholds (in relation to assets, training, income, etc), below which they are unable to compete in a market environment. If it is to have the desired transformative effects the HGSF model must help push households over these thresholds. However, this can be challenging as vulnerability often arises because farm households are constrained by multiple thresholds simultaneously.

Thresholds imply non-linear effects, such that livelihoods are particularly sensitive or vulnerable to changes over particular ranges of certain variables. Three thresholds illuminate possible synergies and conflicts between agricultural and social protection policies. As well as the asset thresholds (Carter and Barrett 2007) where certain combinations or numbers of assets are needed to engage in certain livelihood activities (e.g. two oxen for ploughing), there are price thresholds and market thresholds. Price thresholds occur where an activity only becomes worthwhile above a particular price. Market thresholds occur where low volumes and numbers of market players lead to high coordination risks and transaction costs. This sets up a vicious circle involving low levels of economic activity with few market players and low market volumes, high transport and communication costs, high transaction risks and costs, weak contractual enforcement institutions, high physical and market risks, and supply chain investment disincentives and failures (Dorward and Kydd 2005). All of these constraints on rural livelihoods reinforce the argument made earlier in this paper, that there is a logical convergence between agricultural policy and social protection policy - interventions in assets, prices or markets could benefit both agricultural production and household food security. In other words, it may not be sufficient to intervene on assets, or prices or markets alone. These are important considerations for any HGSF programme.

\subsubsection{Policy complementarities and sequencing effects}

Building on their development coordination hypothesis and drawing on experience from Malawi, Dorward and Kydd (2005) argue that input, output and financial markets are very thin for goods and services in many family farming areas. Moreover, trading costs are high, information services are costly and there is a high risk of transaction failures for buyers and sellers. To cover these imperfections and risks, prices are high which depresses demand. The effect of these conditions as well as the risks associated with variable prices and yields is to trap different players in the supply chains into low-level equilibrium activities and perpetuate widespread market failure: "Specific supply chains needed for rural people to intensify farm production or to start adequately capitalized non-farm enterprises tend to be absent or very weak" (Dorward and Kydd 2005, p.262).

While there has been much debate around the causes and lessons that can be learned from Malawi's 2001/02 food crisis, Dorward et al. (2006), based on the analysis outlined above, use this example to suggest a three-step or sequenced approach to food security and rural poverty reduction:

1. ensuring immediate food security requires policies that will work in the absence of effective markets, implying a dominant role for social safety nets (where the choice 
between cash and food transfers must be based on sound market analysis) and less focus on economic growth;

2. in the medium-term there is a need to develop effective markets and rural infrastructure, while maintaining social protection measures that are sensitive to local market conditions;

3. in the longer term, once markets and traders are well established and rural infrastructure is in place, then market-based policies can be increasingly relied upon to promote food security and rural economic growth.

The crucial point is that sets of policies must be selected that complement each other in achieving short- and long-term objectives, and they should be adjusted over time as circumstances change. In other words, apparent policy synergies between welfare improvements and pro-poor agricultural growth must be exploited sensitively depending on prevailing conditions and evolving priorities at the time. Furthermore, policy instruments need to complement each other at different stages of market development. Sometimes instruments will need to be largely non-market based, but at other times the appropriate instruments will be predominantly market based.

The implication of this argument for HGSF and its ambition to transform agriculture is that it must be located within a broader, long-term development strategy in which policies relating to input and output markets, as well as investments in infrastructure and agricultural research, are tightly coordinated and logically sequenced.

\section{Discussion}

We introduced this paper with reference to the notion that social protection interventions involving food can be used to promote transformational change in family farming systems. Having outlined the theory of change underlying one such intervention - home-grown school feeding - we then examined the types of agricultural development benefits that might be expected to arise and some of the factors that might moderate these benefits.

This analysis has highlighted the complexity of pathways to agricultural transformation associated within the seemingly simple idea of HGSF. So, while there in increasing interest in and enthusiasm for HGSF, whether, and in what situations, HGSF is likely to stimulate a transformation in family farming are open questions that demand further theoretical and empirical attention. An almost complete lack of data on the operation of these programmes in SSA limits empirical analysis, and any evaluation programmes that are put in place will need to take account of the many potential pathways for positive change that were identified above.

The tendency is to call on notions of "win-win" and synergy to present HGSF as a single intervention that can address both social protection and agricultural development objectives. An alternative is to see HGSF as two separate instruments (school feeding and structured demand) addressing two independent policy objectives (child welfare and agricultural development). By explicitly separating school feeding from structured demand this conception can help focus attention on the details of procurement as the main intervention driving agricultural change. It should also help facilitate more meaningful evaluation of HGSF programmes. 
Another area where much greater clarity is required is around the use of the word local in relation to HGSF. This word is central to HDSF discourse: in Home Grown: The New Era of School Feeding (Morgan et al. 2007) it appears 838 times (in 477 pages), while in HomeGrown School Feeding: A Framework to Link School Feeding with Local Agricultural Production (Espejo et al. 2009) it is used 124 times (in 80 pages). However neither document spells out clearly what is meant by local. Rather, depending on the context it is used to refer to within the boundary of the village or area surrounding a single school, or at the other extreme, to within the national boundary of the country within which the same school sits. As highlighted above, the spatial dimensions of the school feeding and structured demand sides of HGSF will to some extent determine the type, magnitude and distribution of any agricultural benefits, and thus continued ambiguity around a term as central as local is untenable. ${ }^{9}$

In the remainder of this section we identify areas where additional research would contribute to a better understanding of the agricultural development potential of HGSF. These areas also represent important gaps in understanding of the more general social protection and agricultural development overlap.

\subsection{Are family farmers the same as SMEs?}

We have argued that the interest in structured demand as a central component of HGSF can be linked to broader experience using demand-assisted strategies to promote SME development. Tendler and Amorim's (1996) analysis of examples from northeast Brazil is particularly compelling, and from it they drew five key lessons as to how successful demandassisted growth strategies should be operationalised:

- Procurement units should not be required to buy from small firms: rather, working with a "support agency" these firms must prove they can deliver at the same price and quality as that of the government's existing suppliers.

- Procurement units should contract only with groups of firms, with individual firms being paid only upon delivery and satisfactory inspection of the product of the whole group.

- Procurement units must be willing to make a substantial part of the payment to suppliers up front.

- Support functions must be kept separate from procurement functions.

- The support agency must earn a small commission on the contract

But are these lessons, drawn from experiences with small businesses in Brazil, relevant to family farmers in SSA? In what ways are family farmers analogous to SMEs? ${ }^{10}$ In some respects these questions hark back to earlier framings and debates that portrayed farmers in SSA as "subsistence oriented" and "peasants" on the one hand, or "capitalist farmers" on the others. More recent framings, including those favoured by CAADP and AGRA, highlight the entrepreneurial spirit of Africa's family farmers, while others focus on the fact that

\footnotetext{
${ }^{9}$ This same ambiguity around the term local is found in much of the broader literature on sustainable and alternative food. Born and Purcell (2006) provide an provocative analysis of what they term "the local trap".

${ }^{10}$ Most definitions of micro, small or medium enterprises in SSA implicitly or explicitly exclude family farms (see Rogerson (2001) and Abor \& Quartey (2010)).
} 
farming is only one element of increasingly diversified livelihoods. In contrast, the food sovereignty movement draws on the earlier images of a self-sufficient peasantry. All of these framings are however homogenising to an extreme. In relation to HGSF the key questions are which family farmers have the entrepreneurial characteristic of SMEs, and are they the same farmers as those who are targeted to benefit from the transformative effects of structured demand?

\subsection{Devolution and structured demand}

The notions of "community ownership" and "community control" loom large in the HGSF literature and in discourse around most national HGSF programmes in SSA. While mechanisms are seldom made explicit, the argument seems to be that devolving responsibility to the school level, and thus creating a sense of local ownership, will help ensure good management and financial control, responsiveness to local needs and longterm sustainability. It is in this light that some programmes put considerable emphasis on the role of "school management committees".

One result of the strategy of devolution to school-level is the atomised procurement activities that can be seen in some programmes where a cook may use a local market to procure food for an individual school (see e.g. the Ghana and Nigeria examples in Table 1). This raises important questions, particularly in relation to the ability to effectively structure demand. One might assume, for example, that demand can only be effectively structured if and when a buyer can exercise a significant degree of power in a market. This power might be associated with a number of factors: the scale of procurement in relation to the size of the market; the offer of premium prices; better payment terms and so on. However, the scale of procurement might be the critical factor. A cook going into a busy market on a daily or weekly basis to procure food for a single school (essentially a spot market transaction) might be expected to have relatively little power. On the other hand, someone buying food on a much larger scale (e.g. for a number of schools and/or for a whole school year) would be in much stronger position to set or negotiate terms (i.e. quality, origin, delivery schedule, lot size etc) - in other words, to actively structure the demand.

This points to what might be an important tension at the heart of HGSF: while devolution of day-to-day management may be desirable or even necessary in some situations, it may at the same time reduce the ability to structure demand, and thus undermine the HGSF theory of change. A more detailed understanding of the factors enabling effective structuring of demand is required, with a particular emphasis on the question of scale.

\subsection{Delivery mechanisms for supply-side measures}

It is clear that there will be few if any agricultural development benefits from HGSF if there is no accompanying increase in farm productivity. For many parts of SSA such productivity increases will be dependent on improved access to information, training, technology, inputs and production credit. In other words, in addition to the whole question of how demand can be structured, there are significant coordination and delivery challenges that both state-funded agricultural extension services and NGOs may struggle to meet. If structured demand is to have the desired effect it will be important to focus on "shortage of resources." As Lipton reminds us, the state should take care not to "unleash private investment demands without providing the resources to satisfy them" (Lipton 1962, p.651).

In designing HGSF programmes the implications of different procurement models and scales of procurement for the effective and efficient provision of supply-side measures to family 
farmers will need to be carefully considered. Over the years there have been many different approaches to (a lot of criticism of) agricultural extension in SSA (Rivera 1996; Rivera and Sulaiman 2009). On the other hand, similar models have played important roles in rapid agricultural change in other parts of the developing world, and in the last decade there has been much interest in new extension models based on "social learning" such as farmer field schools (Godtland et al. 2004; Van den Berg and Jiggins 2007). It is critical that those promoting HGSF consider the implications of this experience for the provision of supply-side measures within HGSF, and specifically how the spatial dimensions of different procurement models likely to impact on the logistics and cost of provision.

\subsection{Effects on HGSF on schooling}

This paper has focused primarily on the agricultural development aspects of the HGSF, leaving the social protection side - the presumed benefits to children's nutrition, health and schooling - unexamined (but see, e.g. Bundy et al. 2009). Nevertheless, there may be important interactions between these two sides of the HGSF proposition that deserve research attention. Under what conditions does the level of centralisation or decentralisation of HGSF programmes create potential for scale economies and/or corruption, that then impact on the amount, quality or consistency of food available? Do these effects have the potential to affect attendance? If, as envisaged, HGSF leads to domestic financing substituting for donor funding, will other elements of school budgets be reduced, thus impacting on the quality of the educational experience? Finally, will HGSF strategies that favour local procurement and preparation make it difficult to integrate foods that have been fortified with micronutrients?

\section{Acknowledgments}

This paper is an output from the initial phase of the Home-Grown School Feeding (HGSF) Project which is funded by Bill \& Melinda Gates Foundation (BMGF) and implemented by the Partnership for Child Development at Imperial College.

We gratefully acknowledge the contributions made to this paper by Mr lain Gardner and Mr Alvaro Pascual Martínez. We also acknowledge the numerous colleagues who made valuable comments on an earlier working paper and the constructive suggestions by two anonymous reviewers. 


\section{References}

Abor, J., and P. Quartey. 2010. Issues in SME Development in Ghana and South Africa. International Research Journal of Finance and Economics 39: 218-228.

Barrett, C. B. 2008. Smallholder market participation: Concepts and evidence from eastern and southern Africa. Food Policy 33(4): 299-317.

Bill \& Melinda Gates Foundation. 2008. Agricultural Development Strategy 2008-2011: Summary Document (marked Confidential). Seattle.

Bill \& Melinda Gates Foundation. 2009. Agricultural Development: Strategy Overview. Seattle.

Bolton, P. 2008. Protecting the environment through public procurement: The case of South Africa. Natural Resources Forum 32(1): 1-10.

Born, B., and M. Purcell. 2006. Avoiding the local trap - Scale and food systems in planning research. Journal of Planning Education and Research 26(2): 195-207.

Bundy, D., C. Burbano, M. Grosh, A. Gelli, M. Jukes, and L. Drake. 2009. Rethinking School Feeding: Social Safety Nets, Child Development, and the Educational Sector, Directions in Development: Human Development. Washington, DC: The World Bank.

Carter, M., and C. Barrett. 2007. Asset thresholds and social protection: a 'think-piece'. IDS Bulletin 38(3): 34-38.

Cooper, Russell, and Andrew John. 1988. Cooordination Failures in Keynesian Models. Quarterly Journal of Economics 103(3): 441-463.

del Ninno, C., P. A. Dorosh, and K. Subbarao. 2007. Food aid, domestic policy and food security: Contrasting experiences from South Asia and sub-Saharan Africa. Food Policy 32(4): 413-435.

Dorward, A., and J. Kydd. 2004. The Malawi 2002 food crisis: the rural development challenge. Journal of Modern African Studies 42(3): 343-361.

Dorward, A., and J. Kydd. 2005. Starter Pack in rural development strategies. In Starter Packs: A Strategy to Fight Hunger in Developing and Transition Countries? Lessons from the Malawi experience, 1998-2003, edited by S. Levy. Wallingford: CABI.

Dorward, A., J. Kydd, and C. Poulton. 2005. Beyond liberalisation: "Developmental coordination" policies for African smallholder agriculture. IDS Bulletin 36(2): 80-85.

Dorward, A., R. Sabates Wheeler, I. MacAuslan, C. Buckley, J. Kydd, and E. Chirwa. 2006. Promoting Agriculture for Social Protection or Social Protection for Agriculture: Policy and Research Issues. Brighton: Future Agricultures Consortium, Institute of Development Studies.

DuPuis, E. M., and D. Goodman. 2005. Should we go "home" to eat?: toward a reflexive politics of localism. Journal of Rural Studies 21(3): 359-371. 
Eckersley, R. 2004. The Green State: Rethinking Democracy and Sovereignty. Cambridge: The MIT Press.

Edwards-Jones, G., L. Mila`i Canals, N. Hounsome, M. Truninger, G. Koerber, B. Hounsome, P. Cross, E.H. York, A. Hospido, K. Plassmann, I.M. Harris, R.T. Edwards, G.A.S. Day, A.D. Tomos, S.J. Cowell, and D.L. Jones. 2008. Testing the assertion that 'local food is best': the challenges of an evidence-based approach. Trends in Food Science \& Technology 19: 265274.

Espejo, F., C. Burbano, and E. Galliano. 2009. Home Grown School Feeding: A Framework to Link School Feeding with Local Agricultural Production. Rome: World Food Programme.

Geng, Y., and B. Doberstein. 2008. Greening government procurement in developing countries: Building capacity in China. Journal of Environmental Management 88(4): 932-938.

Godtland, E. M., E. Sadoulet, A. De Janvry, R. Murgai, and O. Ortiz. 2004. The impact of farmer field schools on knowledge and productivity: A study of potato farmers in the Peruvian Andes. Economic Development and Cultural Change 53(1): 63-92.

Hinrichs, C. C. 2003. The practice and politics of food system localization. Journal of Rural Studies 19: 33-45.

Kremer, M. 1963. The O-Ring theory of economic development. Quarterly Journal of Economics 108: 551-575.

Lentz, E. C., and C. B. Barrett. 2008. Improving food aid: What reforms would yield the highest payoff? World Development 36(7): 1152-1172.

Lipton, M. 1962. Balanced and unbalanced growth in underdeveloped countries. The Economic Journal 72(287): 641-657.

Martinez-Torres, M. E., and P. M. Rosset. 2010. La Via Campesina: the birth and evolution of a transnational social movement. Journal of Peasant Studies 37(1): 149-175.

Maxwell, D. 2007. Global factors shaping the future of food aid: the implications for WFP. Disasters 31: S25-S39.

McCrudden, C. 2004. Using public procurement to achieve social outcomes. Natural Resources Forum 28(4): 257-267.

Morgan, K. 2008. Greening the Realm: Sustainable Food Chains and the Public Plate. Regional Studies 42(9): 1237-1250.

Morgan, K., T. Bastia, and T. Kanemasu. 2007. Home Grown: The New Era of School Feeding. Cardiff: School of City and Regional Planning, Cardiff University.

Morgan, K., and R. Sonnino. 2008. The School Food Revolution: Public Food and the Challenge of Sustainable Development. London: Earthscan.

Poulton, C., J. Kydd, and A. Dorward. 2006. Overcoming market constraints on pro-poor agricultural growth in sub-Saharan Africa. Development Policy Review 24(3): 243-277. 
Rivera, W. M. 1996. Agricultural extension in transition worldwide: structural, financial and managerial strategies for improving agricultural extension. Public Administration and Development 16(2): 151-161.

Rivera, W. M., and V. R. Sulaiman. 2009. Extension: object of reform, engine for innovation. Outlook on Agriculture 38(3): 267-273.

Rogerson, C. M. 2001. In search of the African miracle: debates on successful small enterprise development in Africa. Habitat International 25(1): 115-142.

Sabates-Wheeler, R., S. Devereux, and B. Guenther. 2009. Building Synergies Between Social Protection and Smallholder Agricultural Policies. Brighton: Future Agricultures Consortium \& Centre for Social Protection, Institute of Development Studies.

Sanchez, P., M. S. Swaminathan, P. Dobie, and N. Yuksel. 2005. Halving Hunger: It Can Be Done. UN Millennium Project Task Force on Hunger. London: Earthscan \& Millennium Project.

Sonnino, R. 2009. Quality food, public procurement, and sustainable development: the school meal revolution in Rome. Environment and Planning A 41(2): 425-440.

Stoppa, A. 2007. Background material for the supply sections of the HGSF conceptual framework.

Sumberg, J., and R. Sabates-Wheeler. 2010. Linking Agricultural Development to School Feeding in Sub-Saharan Africa. Working Paper 012. Brighton, UK: Future Agricultures Consortium.

Tadesse, G., and G. Shively. 2009. Food Aid, Food Prices, and Producer Disincentives in Ethiopia. American Journal of Agricultural Economics 91(4): 942-955.

Tendler, J., and M. A. Amorim. 1996. Small firms and their helpers: lessons on demand. World Development 24(3): 407-426.

Van den Berg, H., and J. Jiggins. 2007. Investing in farmers - The impacts of farmer field schools in relation to integrated pest management. World Development 35(4): 663-686.

Winter, M. 2003. Embeddedness, the new food economy and defensive localism. Journal of Rural Studies 19: 23-32. 